\section{Participants, methods, and results}

The research priorities outlined for developing countries in the Global Forum for Health Research's report for 2000 are child health and nutrition (including diarrhoea, pneumonia, HIV, tuberculosis, malaria, other vaccine preventable diseases, and malnutrition); maternal and reproductive health (including mortality, nutrition, sexually transmitted diseases, HIV, and family planning); non-communicable diseases (including cardiovascular diseases, mental illness, and disorders of the nervous system); injuries; and health systems and health policy research. ${ }^{1}$ We compared these research priorities with the content in four leading medical journals: Lancet, BMJ, New England Journal of Medicine, and JAMA. A single observer, from a developing country, systematically reviewed all the articles published in these journals during January 2002 and January 2003 for relevancedefined as concordance with the Global Forum's priorities-to developing countries.

In January 2002, 17 issues of these journals were published, containing 784 articles, of which 135 (17\%) were relevant to research priorities of developing countries. In January 2003, a similar number of issues contained 725 articles, of which 104 (14\%) were relevant. However, the data show important transatlantic differences. The Lancet and BMJ had better coverage, with 102/461 (22\%) and 110/515 (21\%) of articles relevant to developing countries compared with $17 / 318(5 \%)$ and $10 / 215(5 \%)$ of articles published in JAMA and the New England Journal of Medicine. The difference between UK and US journals was significant $\left(\chi^{2}=71.74, \quad \mathrm{P}<0.001\right)$. The table shows detailed information on various types of articles, showing that the transatlantic divide in original research articles is even more pronounced than that for total content.

\section{Comment}

This study shows a transatlantic divide in publication of articles relevant to problems of developing countries: UK journals contained more such articles than did US journals. The results may have differed if the study had been done over a longer period of time. In particular, the publication of theme issues might affect a journal's numbers. None of the journals had a theme issue on

\section{What is already known on this topic}

The content of medical journals vastly under-represents the diseases affecting populations in developing countries

\section{What this study adds}

A "transatlantic divide" exists-compared with two leading US medical journals, two leading UK medical journals publish much more content relevant to developing countries

global health during 2002 or 2003, although the BMJ had one in January 2002 on "Global voices on the AIDS catastrophe," possibly inflating its numbers. An earlier study conducted during the first eight months of 2001 showed similar results for three of the journals, although in that dataset the distinction between the $B M J$ and the two US journals was less pronounced. ${ }^{4}$ JAMA had a theme issue on global health in June 2004, perhaps signalling an improvement in its numbers beyond the period of this study. ${ }^{5}$

Hopefully we will see this transatlantic gap close. We recommend audit of leading medical journals at regular intervals for content relevant to developing countries and publication of the results.

Contributors: Both authors had the idea, developed the design, and wrote the manuscript. AJR collected and analysed the data and is the guarantor.

Funding: PAS is supported by a distinguished investigator award from the Canadian Institutes of Health Research; AJR and PAS are supported by grants from the Fogarty International Center of the US National Institutes of Health.

Competing interests: Both authors are members of the $B M J \mathrm{~s}$ ethics committee.

Global Forum for Health Research. The $10 / 90$ report on health research 2000. Geneva: World Health Organization, 2000.

Dickson D. Scientific output: the real 'knowledge divide'. SciDevNet, July

Dickson D. Scientific output: the real 'knowledge divide'. SciDevNet, July
19, 2004. www.scidev.net (accessed 16 Aug 2004).
Keiser J, Utzinger J, Tanner M, Singer BH. Representation of authors and editors from countries with different human development indexes in the leading literature on tropical medicine: survey of current evidence. $B M J$ 2004;328:1229-32.

4 Obuaya C. Reporting of research and health issues relevant to resource poor countries in high impact medical journals. Eur Sci Editing 2002;28(3):72-7.

5 Flanagin A, Winker MA. Global health-targeting problems and achieving solutions. JAMA 2003;290:1382-4.

\title{
Did the US boycott of French products spread to include scientific output?
}

Bernard Bégaud, Hélène Verdoux

EA 3676, IFR99 of Public Health, Université Victor Segalen Bordeaux 2, Bordeaux, France Bernard Bégaud professor of pharmacology Hélène Verdoux professor of psychiatry

continued over

BMJ 2004;329:1430-1
The French opposition to military intervention in Iraq induced a marked anti-French protest in the United States, leading to a boycott of French products. This phenomenon began in February 2003, peaked in early March 2003 after the French veto at the United Nations Security Council, and has continued ever since. During this period, there was a persistent rumour among French researchers that the boycott of French goods had spread to include scientific outputthat is, that US journals were tending to reject manuscripts submitted by French research groups. As the rumour was based on subjective impressions and not on any numerical evidence, we investigated whether the proportion of French papers published in leading US journals differed in the periods before and after the French veto.

\section{Methods and results}

To avoid any suspicion about the choice of the journals to be investigated, we restricted the analysis among 
weekly journals to the four leading medical journals (New England Journal of Medicine, JAMA, Lancet, BMJ) and the two leading multidisciplinary science journals (Nature, Science). Because of the time lag between submission and publication, we assumed that any effect of the French veto on publication rates would be delayed by at least three months in journals with weekly publications. We therefore conducted a Medline search for the period July 2002 to June 2004 to identify all papers mentioning one of the 15 European Union (EU) countries in the authors' addresses. We categorised the papers according to time of publication (before or after the French veto), nationality of journals (US or UK), and country of authorship.

The number of French papers published in the US journals decreased after the French veto, with an almost symmetrical increase in the number of French papers published in the UK journals (table). For most other EU countries, the change over time in the number of papers published in US or UK journals was in the same direction for both these groups of journals. We found a similar pattern for Belgium to that for France, whereas we found a reverse pattern for Germany, and to a lesser extent for Denmark.

\section{Commentary}

The number of French papers published in US journals decreased after the French veto of military action in Iraq, and simultaneously increased in UK journals. As we could not document rejection rates, we cannot exclude the possibility that French researchers might have decided to avoid US journals as a reaction to the US anti-French campaign and preferred to submit their work to UK journals, although the attractive impact factors and reputation of US journals make this hypothesis unlikely. Our decision to assess only high impact journals, which presumably publish high quality papers, might have underestimated any effect since the influence of non-scientific criteria (such as geographical bias) on the acceptance rate might be less pronounced for papers of high scientific quality than for those submitted to lower ranking journals.

\section{What is already known on this topic}

Editorial decisions may be influenced by the country of origin of submitted papers, but little is known of the impact of major political events on such decisions

\section{What this study adds}

The French veto of military intervention in Iraq might have induced a US boycott of French scientific output, as suggested by the decrease in the number of French papers published in leading US journals after the veto

Although Germany supported the French position, the number of German papers in the US journals increased over the two periods. This finding is not contradictory with a specific boycott of French scientific output as no marked anti-German protest arose in the United States.

Although editorial decisions in medical and scientific journals should be based solely on scientific criteria, ${ }^{1}$ this is not always $\mathrm{so}^{2}$ and the country of origin of submitted papers may influence reviewers' decisions, ${ }^{3}$ but little is known about the influence of major political events on such decisions. Although no definite conclusion can be drawn from the present findings, they suggest that the rumour of a US boycott of French scientific output is not totally groundless.

Contributors: HV collected the data. Both authors contributed to the study design, interpretation of results, and writing of the manuscript. Both are guarantors.

Funding: None.

Competing interests: None declared.

1 World Association of Medical Editors. WAME policy statements: Geopolitical intrusion on editorial decisions. www.wame.org Geopolitical intrusion on editorial decisions.
wamestmt.htm\#geopolitical (accessed 10 Nov 2004).

2 Ray JG. Judging the judges: the role of journal editors. OJM 2002;95:76974.

3 Link AM. US and non-US submissions: an analysis of reviewer bias.JAMA 1998;280:246-7.

Papers from EU countries published in leading UK and US medical and multidisciplinary science journals before and after French veto of military intervention in Iraq. Values are numbers (percentages of EU papers) of Medline citations* unless stated otherwise

\begin{tabular}{|c|c|c|c|c|c|c|c|c|c|}
\hline \multirow[b]{2}{*}{ EU country } & \multicolumn{3}{|c|}{ UK journals† } & \multicolumn{3}{|c|}{ US journalsł } & \multicolumn{3}{|c|}{ Total journals } \\
\hline & $\begin{array}{l}\text { July 2002- } \\
\text { June } 2003\end{array}$ & $\begin{array}{l}\text { July 2003- } \\
\text { June } 2004\end{array}$ & $\begin{array}{c}\% \\
\text { change }\end{array}$ & $\begin{array}{l}\text { July 2002- } \\
\text { June } 2003\end{array}$ & $\begin{array}{l}\text { July 2003- } \\
\text { June } 2004\end{array}$ & $\begin{array}{c}\% \\
\text { change }\end{array}$ & $\begin{array}{l}\text { July 2002- } \\
\text { June } 2003\end{array}$ & $\begin{array}{l}\text { July 2003- } \\
\text { June } 2004\end{array}$ & $\begin{array}{c}\% \\
\text { change }\end{array}$ \\
\hline France & $68(5.2)$ & $80(6.4)$ & 17.6 & 65 (14.3) & $56(12.0)$ & -13.8 & $133(7.5)$ & $136(7.8)$ & 2.3 \\
\hline Other EU countries§: & $1246(94.8)$ & $1188(93.6)$ & -4.7 & $387(85.7)$ & $411(88.0)$ & 6.2 & $1633(92.5)$ & 1599 (92.2) & -2.1 \\
\hline Austria & $22(1.7)$ & $16(1.3)$ & -27 & $13(2.9)$ & $12(2.6)$ & -7.7 & $35(2.0)$ & $28(1.6)$ & -20.0 \\
\hline Belgium & $16(1.2)$ & $22(1.7)$ & 37.5 & $11(2.4)$ & $7(1.5)$ & -36.4 & $27(1.5)$ & $29(1.7)$ & 7.4 \\
\hline Denmark & $31(2.4)$ & $29(2.3)$ & -6.5 & $15(3.3)$ & $18(3.9)$ & 20.0 & $46(2.6)$ & $47(2.7)$ & 2.2 \\
\hline Finland & $19(1.4)$ & $14(1.1)$ & -26.3 & $8(1.8)$ & $7(1.5)$ & -12.5 & $27(1.5)$ & $21(1.2)$ & -22.2 \\
\hline Greece & $3(0.2)$ & $3(0.2)$ & 0 & $4(0.9)$ & $1(0.2)$ & -75.0 & $7(0.4)$ & $4(0.2)$ & -42.9 \\
\hline Germany & $137(10.4)$ & $133(10.4)$ & -2.9 & $81(17.9)$ & $104(22.3)$ & 28.4 & $218(12.4)$ & $237(13.7)$ & 8.7 \\
\hline Italy & $49(3.7)$ & $47(3.7)$ & -4.1 & $27(6.0)$ & $26(5.6)$ & -3.7 & $76(4.3)$ & $73(4.2)$ & -3.9 \\
\hline Ireland & $9(0.7)$ & $12(0.9)$ & 33.3 & $3(0.6)$ & $6(1.3)$ & 100 & $12(0.6)$ & $18(0.1)$ & 50 \\
\hline Luxembourg & 0 & 0 & 0 & 0 & 0 & 0 & 0 & 0 & 0 \\
\hline Netherlands & 81 (6.1) & $100(7.9)$ & 23.5 & $38(8.4)$ & $41 \quad(6.7)$ & 7.9 & $119(6.7)$ & 141 (8.1) & 18.5 \\
\hline Portugal & $1(0.1)$ & $3(0.2)$ & 200 & 0 & $1(0.2)$ & 100 & $1(0.05)$ & $4(0.2)$ & 300 \\
\hline Spain & $11(0.8)$ & $15(0.1)$ & 36.4 & $7(0.2)$ & $14(0.3)$ & 100 & $18(0.1)$ & $29(0.2)$ & 61.1 \\
\hline Sweden & 38 (2.3) & $32(2.5)$ & -15.9 & $20(4.4)$ & $13(2.8)$ & -35.0 & 58 (3.2) & $45(2.6)$ & -22.4 \\
\hline UK & $829(63.1)$ & $762(60.1)$ & -8.1 & $160(35.4)$ & $161(34.5)$ & 0.6 & $989(56.0)$ & $923 \quad(53.2)$ & -6.7 \\
\hline Total & 1314 (100) & $1268(100)$ & -3.5 & $452(100)$ & $467(100)$ & 3.3 & $1766(100)$ & 1735 (100) & $\begin{array}{l}-1.8 \\
\end{array}$ \\
\hline
\end{tabular}

*Some papers may have been counted more than once, as papers with authors from more than one country mentioned in the authors' addresses were counted for each country. †Nature, Lancet, BMJ. ‡Science, New England Journal of Medicine, JAMA. §15 countries were EU members during this period.

Correspondence to: B Bégaud, Bâtiment Présidence, Université Victor Segalen Bordeaux 2,33076, Bordeaux cedex, France

bernard.begaud@ pharmaco. u-bordeaux2.fr 